\title{
Real-Time PCR-Based Monitoring of DNA Pools in the Tri-Trophic Interaction Between Norway Spruce, the Rust Thekopsora areolata, and an Opportunistic Ascomycetous Phomopsis sp.
}

\author{
Ari M. Hietala, Halvor Solheim, and Carl Gunnar Fossdal
}

Norwegian Forest and Landscape Institute, Pb. 115, NO-1431 Ås, Norway.

Accepted for publication 19 June 2007.

\begin{abstract}
Hietala, A. M., Solheim, H., and Fossdal, C. G. 2008. Real-time PCRbased monitoring of DNA pools in the tri-trophic interaction between Norway spruce, the rust Thekopsora areolata, and an opportunistic ascomycetous Phomopsis sp. Phytopathology 98:51-58.

The difficulty in subculturing biotrophic fungi complicates etiological studies related to the associated plant diseases. By employing internal transcribed spacer rDNA-targeted quantitative real-time polymerase chain reaction, we now show that the heteroecious rust Thekopsora areolata, commonly associated in natural conditions to sapling shoots and cones of Norway spruce and leaves of wild bird cherry, frequently infects nurserygrown seedlings of the conifer. A spatial sampling scheme was used to investigate seedlings and saplings of Norway spruce showing phloem
\end{abstract}

ABSTRACT necrosis: the highest concentration of DNA of T. areolata was recorded in the area with necrotic phloem. The separate analysis of bark and wood tissues suggested that the initial spread of the rust to healthy tissues neighboring the infection site takes place in the bark. A Phomopsis species found to coexist with $T$. areolata in several seedlings showed very high DNA levels in the upper part of the lesion, and even in the visually healthy proximal tissues above the lesions, which indicates that the ascomycete, most probably a secondary invader following primary infection by $T$. areolata, has a latent stage during early host colonization. We hypothesize that this hemibiotrophic mode of infection contributes to the successful coexistence of Phomopsis with a biotrophic rust.

Additional keywords: hemibiotrophy, infection, Picea abies.
Thekopsora areolata (Fr.) P. Magn. (Pucciniastrum areolatum (Fr.) Otth, Pucciniastrum padi (Schm. \& Kunze) Diet.) is a Eurasian rust fungus recorded from England through the whole of Europe and from Russia to Kamtschatka and Japan $(6,10,21)$. The fungus alternates between conifers and broadleaved trees in order to complete its life cycle with five distinct spore stages. Its main hosts are Norway spruce (Picea abies (L.) Karst.) and wild bird cherry (Prunus padus L.) (20).

T. areolata overwinters as telia in the leaves of wild bird cherry shed on the ground. In spring during rainy weather, the teliospores germinate and form basidiospores in synchrony with the flowering of Norway spruce. Female flowers of spruce, that eventually give rise to cones, are infected by basidiospores carried by air currents. Following the formation of pycnia on the outer sides of the cone scales and spermatization, dikaryotic hyphae form aecidia on both sides of the cone scales during the summer (6). The aecidia mature and open next spring and release aecidiospores, which infect cherry leaves. The scales of infected cones are characteristically spread apart from each other and no seeds are formed in infected cones, which often remain attached to shoots longer than the healthy ones. Basidiospores of $T$. areolata may also infect actively growing shoots of spruce, the fast-growing terminal shoots of spruce saplings being especially susceptible. Infected shoots usually become crooked, S-formed, with some dead tissue in the crooked part, and the shoots often die above the crook $(13,19)$.

In a project focused on diseases of Norway spruce, we have been investigating the etiology of bark necrosis in nursery seed-

Corresponding author: A. M. Hietala

E-mail address: Ari.Hietala@ Skogoglandskap.no

doi:10.1094/PHYTO-98-1-0051

(C) 2008 The American Phytopathological Society lings. Seedlings showing typical symptoms of $T$. areolata infection were often observed in forest nurseries, but no fruit bodies of the rust were observed in these seedlings. An ascomycete, a Phomopsis species, was now frequently codetected with T. areolata in these diseased shoots of Norway spruce. While necrotrophic fungi can trigger a hypersensitive response and programmed cell death in the host plant to feed subsequently as saprotrophs (7), rusts rely on haustoria in extracting nutrients from living host cells and enable their parasitic relationships with plants by longterm suppression of host defense responses (23). Due to this nutritional mode, biotrophic fungi such as rusts are difficult to culture on artificial media; however, the development of real-time polymerase chain reaction (PCR) technology has provided a powerful tool for quantitative detection of unculturable microbes in their natural substrates (9). To study the interaction of T. areolata, Phomopsis sp., and the hosting Norway spruce, we developed real-time PCR assays to quantify their DNA pools at the advancing margins of the lesions in diseased shoots.

\section{MATERIALS AND METHODS}

Sampling. A total of 100 2-year-old containerized nursery seedlings of Norway spruce that showed necrotic stem lesions with a slightly swollen bark area (Fig. 1) were collected from three different nurseries. To first screen the seedlings for the presence of candidate pathogens, a 5-mm-long bark sample was taken from the middle of the lesion from 50 randomly selected seedlings and processed for DNA analysis as described below. After this initial screen, 18 seedlings were sampled by taking 5-mmlong samples from the edges of the lesion area in order to obtain spatial colonization profiles. To examine tissue-specific colonization, the bark in the lesion area was separated from the wood with a scalpel in five seedlings, and the samples were processed separately for DNA isolation. In addition to diseased nursery seed- 
lings, T. areolata-infected cones and shoots of naturally grown saplings of Norway spruce and the leaves of wild bird cherry were collected for DNA isolation/colonization profiling and internal transcribed spacer (ITS) rDNA sequence comparisons. These samples were collected from various localities in Norway, the sampling area stretching from Kristiansand in southern Norway to Stjørdal in central Norway covering a distance of $800 \mathrm{~km}$ (Table 1).

DNA isolation, cloning, and sequence analysis. For DNA isolation, infected bark and wood samples from Norway spruce were excised, frozen immediately in liquid $\mathrm{N}_{2}$, and ground in

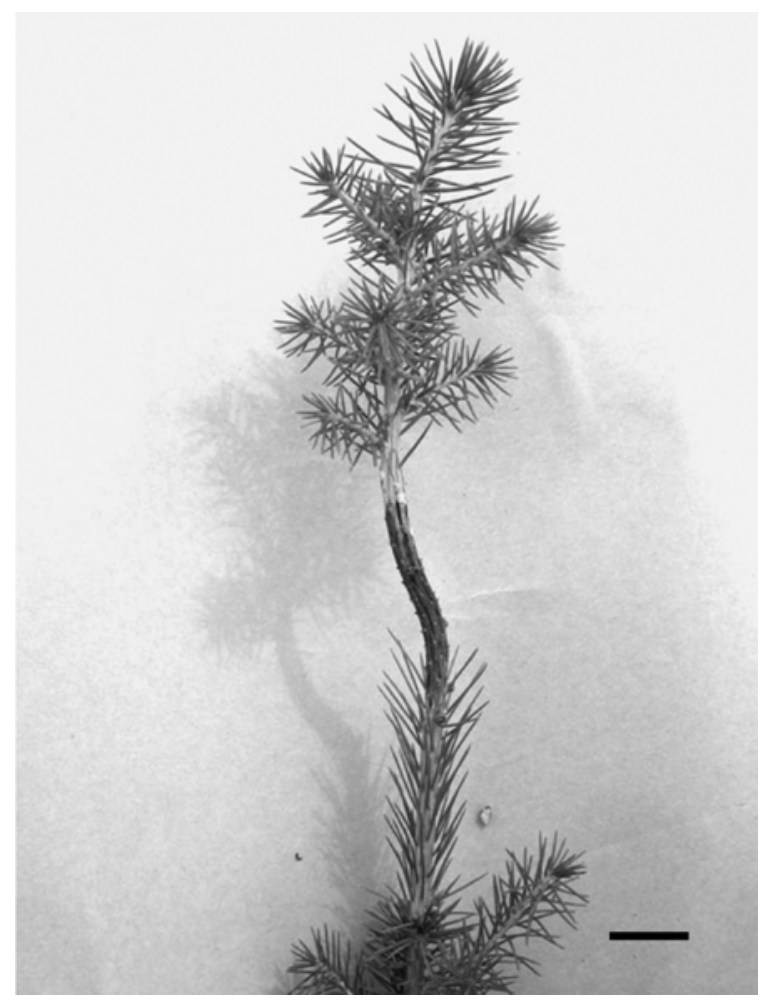

Fig. 1. The 2-year-old Norway spruce seedling Bu4 showing typical symptoms of Thekopsora areolata infection: crooked stem with dark brown, slightly swollen bark area with resin flow $($ bar $=1 \mathrm{~cm})$. liquid $\mathrm{N}_{2}$-chilled containers for 2 min in an MM 300 mill (Retsch Gmbh, Haan, Germany). Uredinia samples from T. areolatainfected leaves of wild bird cherry and aecidia samples from Norway spruce cones were ground with a pestle in an Eppendorf tube. To obtain negative references for testing the specificity of the real-time PCR assays used for quantifying Norway spruce and T. areolata DNA in diseased seedlings, the following strains of fungi commonly associated with diseased shoots of Norway spruce seedlings were cultured on cellophane-coated malt extract agar (2\% malt extract and $1.5 \%$ agar) for DNA isolation: Alternaria sp. (strain 2006-210), Botrytis cinerea Pers. (strain 1983145/1 Øa), Epicoccum nigrum Link (strain 1959-1898/1/1), Fusarium sp. (strain 2006-221), Gremmeniella abietina (Lagerberg) Morelet (strain 2002-26/2), Herpotrichia juniperi (Duby) Petrak (strain 1973-53), Nectria fuckeliana Booth (strain 1973-74), Phoma sp. (strain 2006-229), Phomopsis sp. (strain 2002-62/1), Rhizosphaera kalkhoffii Bubak (strain 1997-1/6), Sirococcus conigenus (D.C.) P.F. Cannon \& Minter (strain 2000-58/2), and Tiarasporella parca (Berk and Broome) Whithey (strain 1991727/28) (all these isolates were obtained from the culture collection of the Norwegian Forest and Landscape Institute). In addition, aecidia samples of Cronartium ribicola (collection Ru29) and C. flaccidum (collection Ru30) were included as negative reference material. DNA isolation was performed with the Plant DNA Mini Isolation Kit (Qiagen, Hilden, Germany) according to the manufacturer's instructions.

Amplification was carried out with ITS1-F and ITS4-B primers (5) in $25-\mu$ reaction volumes using HotStarTaq DNA Polymerase (Qiagen) according to the manufacturer's instructions. After gel electrophoresis, the PCR products were purified with GFX PCR DNA and Gel Band Purification kit (Amersham Biosciences, Little Chalfont, England), ligated into a cloning vector (pGEM-T Easy; Promega, Madison, WI), and transformed into Escherichia coli $(\mathrm{DH} 5-\alpha)$. For sequencing, plasmid DNA was isolated and purified using Wizard Plus Minipreps (Promega). Three distinct colonies were sequenced in both directions on an ABI PRISM 3100 Genetic Analyzer (Applied Biosystems, Foster City, CA). The alignments of complementary strands and the similarity studies within sequenced samples and other known published ITS regions in the NCBI GenBank sequence database were determined with Seqman software (Lasergene, DNASTAR Inc., Madison, WI).

TABLE 1. Rust samples sequenced for internal transcribed spacer rDNA region in the study

\begin{tabular}{|c|c|c|c|c|c|c|c|}
\hline Code & Rust & Host & Source & Spore stage & Locality & Collector ${ }^{\mathrm{a}}$ & $\begin{array}{c}\text { Accession } \\
\text { no. }\end{array}$ \\
\hline Bu4 2 & Thekopsora areolata & Picea abies & Seedling & None detected & Buskerud, Øvre Eiker, Hokksund & 1 & EF363336 \\
\hline Bu5 10 & Thekopsora areolata & Picea abies & Seedling & None detected & Buskerud, Øvre Eiker, Hokksund & 1 & DQ445891 \\
\hline LR 4B & Thekopsora areolata & Picea abies & Seedling & None detected & Telemark, Sauherad, Gvarv & 1 & DQ445892 \\
\hline LR 14BA & Thekopsora areolata & Picea abies & Seedling & None detected & Telemark, Sauherad, Gvarv & 1 & DQ445894 \\
\hline Sk1 10 & Thekopsora areolata & Picea abies & Seedling & None detected & Sør-Trøndelag, Melhus, Skjerdingstad & 1 & DQ445901 \\
\hline Spl 15 & Thekopsora areolata & Picea abies & Seedling & None detected & Sør-Trøndelag, Melhus, Skjerdingstad & 1 & DQ087229 \\
\hline Spl3 5 & Thekopsora areolata & Picea abies & Seedling & None detected & Sør-Trøndelag, Melhus, Skjerdingstad & 1 & DQ087229 \\
\hline Thek 1 & Thekopsora areolata & Picea abies & Cone & Aecidia & Østfold, Eidsberg, Ramstad & 1 & DQ445895 \\
\hline Thek 2 & Thekopsora areolata & Picea abies & Cone & Aecidia & Østfold, Eidsberg, Ramstad & 1 & DQ087230 \\
\hline Thek 3 & Thekopsora areolata & Picea abies & Cone & Aecidia & Østfold, Eidsberg, Ramstad & 1 & DQ445896 \\
\hline Thek 4 & Thekopsora areolata & Picea abies & Cone & Aecidia & Hedmark, Trysil, Bekkvang & 1 & DQ445897 \\
\hline Thek 5 & Thekopsora areolata & Picea abies & Cone & Aecidia & Hedmark, Trysil, Bekkvang & 1 & DQ445898 \\
\hline Thek 7 & Thekopsora areolata & Picea abies & Cone & Aecidia & Nord-Trøndelag, Stjørdal, Hegra & 2 & DQ445899 \\
\hline Sta1 & Thekopsora areolata & Picea abies & Sapling & Aecidia & Hedmark, Stange, Tangen & 1 & DQ445902 \\
\hline Sta2 & Thekopsora areolata & Picea abies & Sapling & None detected & Hedmark, Stange, Tangen & 1 & DQ445903 \\
\hline $2 \mathrm{~A}$ & Thekopsora areolata & Prunus padus & Leaf & Uredinia & Nord-Trøndelag, Stjørdal, Lånke & 2 & DQ445904 \\
\hline $\mathrm{Ru} 4$ & Thekopsora areolata & Prunus padus & Leaf & Uredinia & Aust-Agder, Birkenes, Birkeland & 1 & DQ087231 \\
\hline Ru5 & Thekopsora areolata & Prunus padus & Leaf & Uredinia & Vest-Agder, Kristiansand, Kroken & 1 & DQ445900 \\
\hline Hall & Thekopsora areolata & Prunus padus & Leaf & Uredinia & Østfold, Halden, Lundene & 1 & DQ445905 \\
\hline Ru6 & Pucciniastrum ebilobii & Epilobium angustifolium & Leaf & Uredinia & Vest-Agder, Kristiansand, Foss & 1 & DQ445906 \\
\hline Ru11 & Pucciniastrum ebilobii & Epilobium watsonii & Leaf & Uredinia & Vest-Agder, Kristiansand, Foss & 1 & DQ445907 \\
\hline Ru29 & Cronartium ribicola & Pinus peuce & Stem & Aecidia & Buskerud, Øvre Eiker, Hokksund & 1 & DQ445908 \\
\hline
\end{tabular}

a 1, H. Solheim; and 2, A. Hietala. 
Oligonucleotide primers used for quantification of the host and pathogen. The real-time PCR primers used for monitoring T. areolata colonization in infected seedlings were designed with the Primer Express software 1.5a provided with Applied Biosystems real-time quantitative PCR systems (Applied Biosystems) by employing a conserved and species-specific sequence area in the ITS rDNA gene cluster. The amount of Norway spruce DNA in analyzed samples from infected nursery seedlings was estimated by using the polyubiquitin primer/probe set previously described (9). In addition, we monitored the presence of G. abietina and Phomopsis sp., pathogenic fungi commonly associated with necrotic stem lesions in Norway spruce seedlings, with primer/ probe sets described by Børja et al. (3). The primer/probe sets used are shown in Table 2.

PCR conditions and specificity of primers. The real-time PCR detection of $T$. areolata DNA was performed in SYBR Green PCR Mastermix (P/N 4309155; Applied Biosystems), while amplification of Norway spruce, G. abietina, and Phomopsis DNA was performed with TaqMan Universal PCR Master Mix (P/N 4304437; Applied Biosystems). A primer concentration of $50 \mathrm{nM}$ was chosen for the $T$. areolata primers, while the primer and probe concentrations of 150 and $333 \mathrm{nM}$ (9), respectively, were used for detecting the DNA of Norway spruce. For G. abietina and Phomopsis sp., a primer concentration of $300 \mathrm{nM}$ and a probe concentration of $400 \mathrm{nM}$ were used (3). All PCR analyses were performed in singleplex conditions.

To construct standard curves for quantification of Norway spruce and pathogen DNA, DNA isolated from a visually healthy control seedling where DNA of T. areolata or Phomopsis sp. could not be detected by real-time PCR, from aecidia of T. areolata formed on a naturally infected cone of the sample Thek2 (Table 1), and from a pure culture of Phomopsis sp. (strain 200262/1) was quantified by a Versafluor fluorometer (Bio-Rad, Hercules, CA) and a PicoGreen DNA quantification kit (Molecular Probes, Eugene, Oregon) and then pooled together in known concentrations. The host DNA standard curve samples $(100,10$, 1 , and $0.1 \mathrm{ng}$ of Norway spruce DNA) were all spiked with $1 \mathrm{ng}$ of T. areolata and $1 \mathrm{ng}$ of Phomopsis sp. DNA. The T. areolata DNA standard curve samples $(100,10,1,0.1,0.01$, and $0.001 \mathrm{pg}$ of $T$. areolata DNA) were all spiked with $1 \mathrm{ng}$ of Norway spruce and $1 \mathrm{ng}$ of Phomopsis sp. DNA. The Phomopsis DNA standard curve samples $(1,000,100,10,1$, and $0.1 \mathrm{pg}$ of Phomopsis sp. DNA) were all spiked with $1 \mathrm{ng}$ of Norway spruce and $1 \mathrm{ng}$ of T. areolata DNA. All the standard curve samples were replicated three times within a single PCR run. To ensure that the cycle threshold $(\mathrm{Ct})$ values $(\mathrm{Ct}$ determines the PCR cycle at which the reporter fluorescence exceeds that of the background) from the experimental samples fell within the standard curves and to investigate the presence of compounds inhibitory to PCR, 3- or 4-log dilution series were prepared for all the experimental samples. Each experimental sample had undiluted DNA as the most concentrated, and all log dilutions of a sample were used as templates in real-time PCR. For both of the series, the experimental and standard curve samples, $3 \mu \mathrm{l}$ of the DNA solution was used as the template for each 25- $\mu$ l PCR. For experimental samples, each reaction was repeated twice in a separate PCR run. PCR cycling parameters were $95^{\circ} \mathrm{C}$ for 10 min followed by 40 cycles of $95^{\circ} \mathrm{C}$ for $15 \mathrm{~s}$ and $60^{\circ} \mathrm{C}$ for $1 \mathrm{~min}$. For $T$. areolata, the PCR cycling was followed by a melting curve analysis: after a denaturation step at $95^{\circ} \mathrm{C}$ for $15 \mathrm{~s}$, the sample was cooled to $60^{\circ} \mathrm{C}$ for $1 \mathrm{~min}$ followed by a linear temperature increase to $95^{\circ} \mathrm{C}$, while continuously monitoring the fluorescent signal. Fluorescence emissions were detected with an ABI Prism 7700 (Applied Biosystems). Data acquisition and analysis were performed with the Sequence Detection System software package (1.7a; Applied Biosystems). Genomic DNA from healthy Norway spruce and from the included reference fungi were used as negative controls for the T. areolata and Phomopsis markers, while fungal DNA served as a negative control for the host marker. To further verify the specificity of the real-time PCR data from experimental samples, selected DNA samples from seedlings were PCR amplified both by the basidiomycete-specific primer pair ITS1-F and ITS4-B and by the universal fungal-specific primer pair ITS1-F and ITS4 (5), followed by sequencing. For this purpose, the PCR products purified with MinElute PCR Purification Kit (Qiagen) were directly sequenced in both directions on an ABI PRISM 3100 Genetic Analyzer (Applied Biosystems) by using the ITS primers as sequencing primers.

Calculation of fungal colonization levels. Standard curves for Norway spruce, T. areolata, and Phomopsis sp. were constructed based on the relationship of $\mathrm{Ct}$ values and known host and pathogen DNA concentrations: the $\mathrm{Ct}$ values were plotted against logtransformed DNA amounts, and linear regression equations were calculated for the quantification of DNA pools in unknown samples.

\section{RESULTS}

Alignment of Thekopsora sequences from different sources. All the $T$. areolata samples studied yielded an 812-bp amplification product with the ITS1-F and ITS4-B primers employed. The corresponding ITS rDNA sequences comprised a 50-bp $3^{\prime}$ end for the 18S rDNA gene, $210 \mathrm{bp}$ in the ITS1 region, $162 \mathrm{bp}$ for the 5.8S rDNA gene, 219 bp in the ITS2 region, and a 171-bp 5' end for the 28S rDNA gene. The ITS1-5.8S-ITS2 sequences from T. areolata samples from different hosts/tissue types showed little variation; the similarities among $T$. areolata sequences obtained from seedlings, saplings, and cones of Norway spruce and from

TABLE 2. Primers/probes used for monitoring pathogen colonization

\begin{tabular}{|c|c|c|c|c|}
\hline Species detected & Primer/probe set ${ }^{\mathrm{a}}$ & Product size (bp) & $\begin{array}{l}\text { Fluorescence } \\
\text { label }\end{array}$ & $\begin{array}{l}\text { Amplicon } \\
\text { melt point }\end{array}$ \\
\hline Thekopsora areolata & $\begin{array}{l}\text { Forward: 5'-TTTGTGCATTGATGGACTTTAAATAAT-3' } \\
\text { Reverse: 5'-CCAAGAGATCCATTGTTAAAAGTTATATGAT-3' }\end{array}$ & 72 & SYBR Green & 69.6 \\
\hline Phomopsis sp. & $\begin{array}{l}\text { Forward: 5'-GCACCCAGAAACCCTTTGTG-3' } \\
\text { Reverse: 5'-AAGAGTTGACTTGGCCGCC-3' } \\
\text { Probe: 5'-CGGTAACGAGGAGCAGCCCGC-3' }\end{array}$ & 116 & FAM & NA \\
\hline Picea abies & $\begin{array}{l}\text { Forward: 5'-TGGTCGTACTCTGGCCGATTATA-3' } \\
\text { Reverse: 5'-ACACCTAGCGGCACACAGTTAA-3' } \\
\text { Probe: 5'-TGCTCCGTCTCCGTGGTGGCT-3' }\end{array}$ & 96 & VIC & NA \\
\hline
\end{tabular}

${ }^{a}$ The primer set for detection of Thekopsora areolata DNA was designed in the present study, while the primer/probe sets for detection of the other two pathogens and host DNA were designed by Børja et al. (3) and by Hietala et al. (9), respectively.

${ }^{b}$ Not applicable. 
leaves of wild bird cherry were 99 to 100,98 to 99,98 to 100 , and 98 to $99 \%$, respectively, while the overall sequence similarity within this material was 98 to $100 \%$. The conserved sequence was compared with sequences from the included reference rusts and with sequences available at the NCBI GenBank sequence database. Among all the sequences available, the rust fungi Puccinia kuehnii (W. Krüger) E.J. Butler, C. ribicola J.C. Fischer, C. flaccidum Alb. \& Schwein, and Peridermium harknessii J.P. Moore showed the greatest similarity to $T$. areolata, but in addition to numerous point mutations in the ITS1 and ITS2 regions, these reference species had a number of inserts in these regions (Fig. 2).

Specificity of the primer/probe sets used and the standard curves constructed. The primer pair now employed for quantifying $T$. areolata colonization in diseased Norway spruce seedlings amplified an 81-bp area between the $3^{\prime}$ end of the ITS1 region and the $5^{\prime}$ end of the 5.8S rDNA gene (Fig. 2). Puccinia

ITS 1

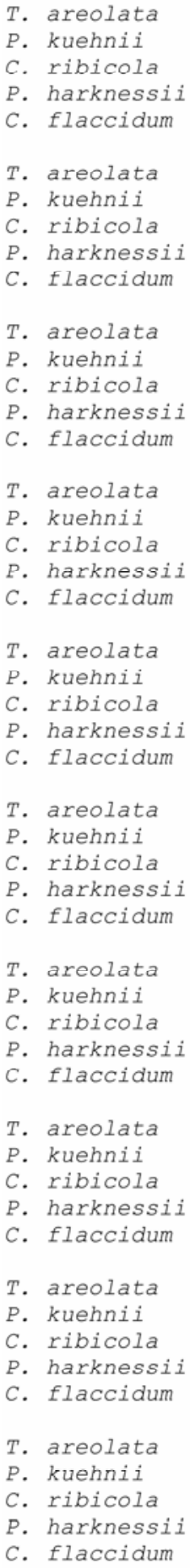
GTAAAGGAGTGCACTTTATT--GTGACTCTGACACTTTTAAATAT---TTAAACCATTTT--AAAC 59

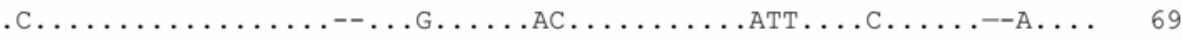

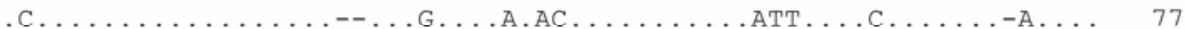
.C............--..G....AC........ATT.C..C........ 77

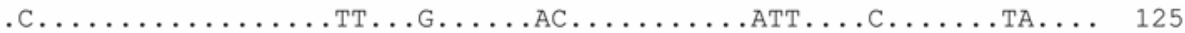
ITS 1

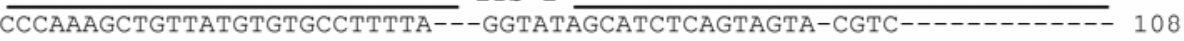

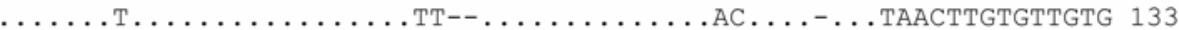

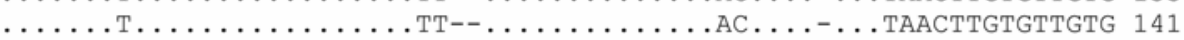

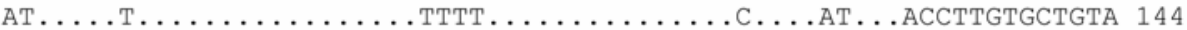

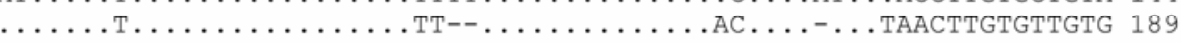
ITS 1

-TTAACATTTGTTTTGACA-TTACCCCCCCTTATAAGTGACCCCCCTTTTTGTGCATTGA-TGGACT 172 T..C...GA.C.C........................T--..А.Т.АCT. 196

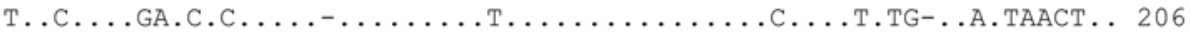

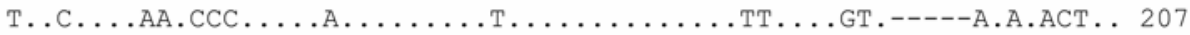
T..C...GA.C.C.................. ITS 1 $5.8 \mathrm{~S}$ rDNA

TTA-AATAATGTT-TTAAGAATGTAAACCCTAT-------A ATCATATAACTTTTAACAATGGATCT2 230

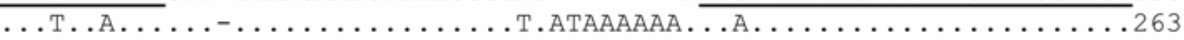

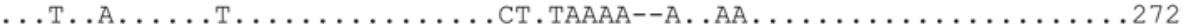

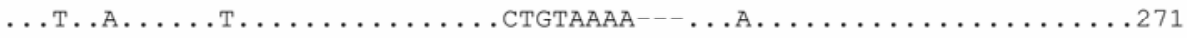

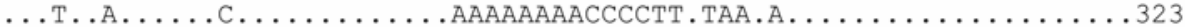
5.8S rDNA $\overline{\text { CTTGGCTCTCACATCGATGAAGAACACA GTGAAATGTGTTAAGTAATGTGAATTGCAGAATTCAGTGA }} 298$

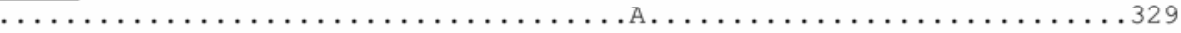

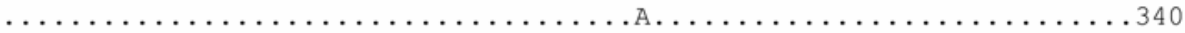

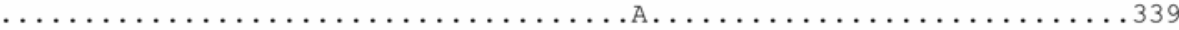

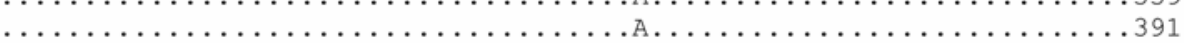

\subsection{S IDNA}

ATCATCGAATCTTTGAACGCACCTTGCACCTTTTGGTATTCCAAAAGGTACACCTGTTTGAGTGTCA 365

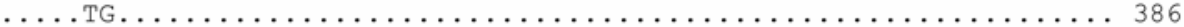

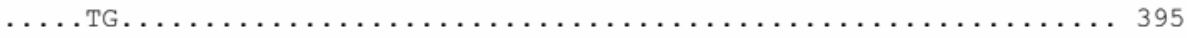

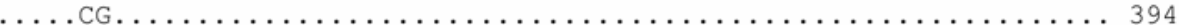

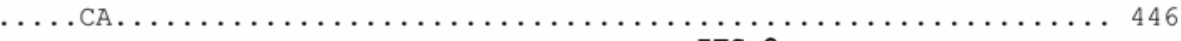
ITS 2

TGAAACCCTCTCATTCTAATTCTT-TATTTGAT-----ATAAGGAGTT----GGTATGGATGTTGAG 424 $\ldots \ldots \ldots \ldots \ldots$. . . . . . . .

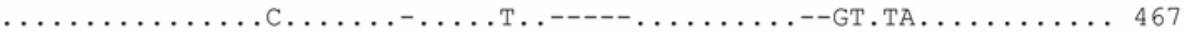

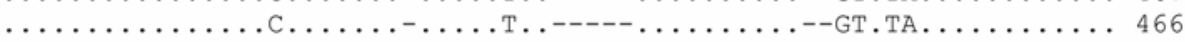
$\ldots \ldots \ldots \ldots \ldots$. ......... ITS 2 TGTTGCCGTCATT----------GGCTCACTTTAAATACATAAGTACTTTTATCTTGAAAAATA-- 476 .....

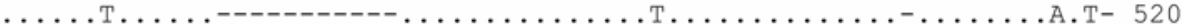

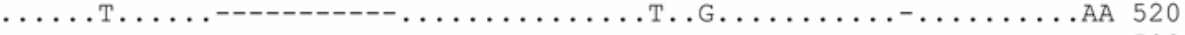

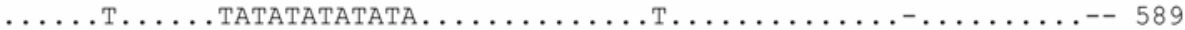

ITS 2

--AATGGAGAAATACTTGGTGTAATATTTAT--GTTTCATTAAGGAGTG TGG-----TTTAATTAC 533

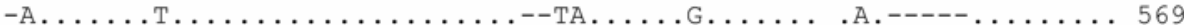

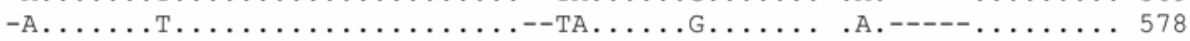

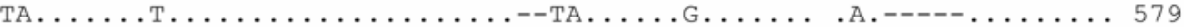

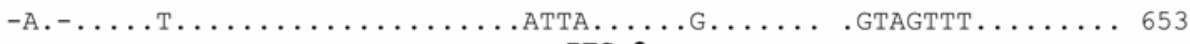

ITS 2

T-ACAGCCATTTGTT--TTGGATAAATAGCTTCCTAACCCTATTATA-TTTAAACTTT

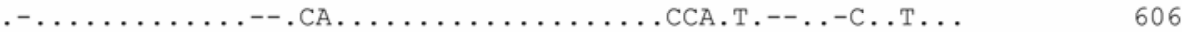

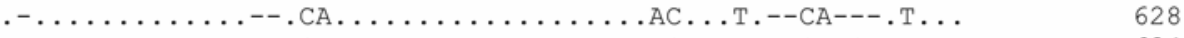

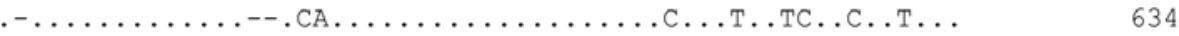

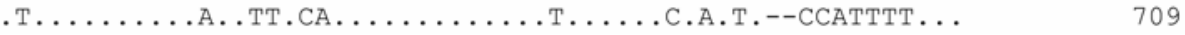

Fig. 2. CLUSTAL W (1.82) multiple sequence alignment of a conserved internal transcribed spacer (ITS) rDNA sequence of Thekopsora areolata (identical sequences obtained from infected seedlings [sample Spl 3 5, accession no. DQ087229] and cones [sample Thek 2, DQ087230] of Norway spruce and from leaves of wild bird cherry [sample Ru4, DQ087231]) and its closest matches at the NCBI GenBank Sequence, Puccinia kuehnii (AJ406049), Cronartium ribicola (L76499), Peridermium harknessii (L76510), and Cronartium flaccidum (AY566270). The $3^{\prime}$ end of $18 \mathrm{~S}$ gene and the $5^{\prime}$ end of 28S gene are not shown in alignment. The line symbol (-) indicates a gap in the alignment, a dot (.) denotes identical nucleotides between the sequences at the given positions. The real-time PCR primers used for quantification of the rust colonization levels in infected seedlings and saplings of Norway spruce are underlined and in bold. 
kuehnii, C. ribicola, C. flaccidum, and Peridermium harknessii (Fig. 2), the included reference rusts and all the other fungal sequences available in the NCBI GenBank sequence database (data not shown), differed from $T$. areolata in several nucleotides in the binding sites of both primers. The primer set developed for monitoring T. areolata did not detect the DNA of Norway spruce, and the primer/probe set used for detecting DNA of Norway spruce did not detect the DNA of $T$. areolata (data not shown). In addition, these two sets did not detect the DNA of the included reference fungi when $1 \mathrm{ng}$ of DNA from these was used as the template. In the standard curve samples constructed for Norway spruce, there was a linear relationship between the $\mathrm{Ct}$ values and the log-transformed amount of DNA in the range of 100 to $0.1 \mathrm{ng}$ of host DNA (Fig. 3A). In the standard curves for T. areolata and Phomopsis sp., there was a linear relationship between the $\mathrm{Ct}$ values and the log-transformed amount of pathogen DNA in the range of 100 to $0.001 \mathrm{pg}$ and 1,000 to $0.1 \mathrm{pg}$, respectively (Fig. $3 \mathrm{~B}$ and $\mathrm{C}$ ). The DNA amount standard curves for Norway spruce, T. areolata, and Phomopsis sp., based on the relationship of the $\log$ amount of template $(x)$ generated from known host and pathogen DNA concentrations and their corresponding $\mathrm{Ct}$ values $(y)$, were $y=29.858-3.591 x, y=23.804-3.4951 x$, and $y=30.337-$ $3.381 x$, respectively. For the Norway spruce, $T$. areolata, and Phomopsis sp. standard curves, the PCR amplification efficiencies (E), calculated with the equation $\mathrm{E}=\left(10^{(-1 / \text { slope })}-1\right) \times 100$, were $89.9,93.2$, and $97.6 \%$, respectively. The melting curve analysis showed a single peak with a melt point of $69.6^{\circ} \mathrm{C}$ in the standard curve samples of T. areolata.

Symptoms of the disease and colonization profiles of $T$. areolata and other fungi monitored. The diseased seedlings and saplings of Norway spruce showed a few centimeter long, dark brown, slightly swollen necrotic bark area with resin flow, and many plants were crooked in the infected area (Fig. 1). On some occasions, the lesions were not distinct and the necrotic tissue was longer (not shown). In the middle of the lesions, both the outer bark and the phloem were dark and necrotic, while at proximal areas above and below this region, the phloem was light brown, eventually transitioning to a green color when examining more distal areas. The change in the phloem color from dark brown to light brown was abrupt, while the transition from light brown to green phloem was often gradual. Fruit bodies (aecidia, pycnia) were not observed in the examined seedlings. Similar symptoms as those observed in the nursery seedlings were also noted in the 5- to 10-m-long saplings included as reference material. Aecidia were observed in one of the leader shoots of these saplings.

T. areolata was detected by real-time PCR in all the seedlings and saplings showing the symptoms described above. As with the standard curve samples, a single peak with a melt point of $69.6^{\circ} \mathrm{C}$ was observed for experimental samples amplified with the $T$. areolata primer pair. To test for the presence of substances inhibitory to PCR, log-dilution series were prepared for all experimental samples. The differences in the corresponding $\mathrm{Ct}$ values between the undiluted and 10-fold diluted DNA samples were, particularly for $T$. areolata, often well below the expected difference of approximately 3.3 cycles (for example, the Thekopsora $\mathrm{Ct}$ values of 17.1, 18.3, and 21.7 were obtained for an undiluted, 10-fold, and 100 -fold diluted sample from seedling Sk4, but only the latter two values are reliable as they gave the expected difference in the $\mathrm{Ct}$ value), which indicates the presence of substances inhibitory to PCR in the undiluted samples and/or excess levels of the template. In contrast, the differences in the corresponding $\mathrm{Ct}$ values between the 10- and 100-fold diluted DNA samples were in the range also observed between the log dilutions of the corresponding standard curves. This compatibility indicates that substances inhibitory to PCR amplification were not present in the diluted samples, and the ten- and hundred-fold diluted DNA samples were subsequently used for calculating the amounts of host and pathogen DNA present in the experimental samples. Within the area colonized by $T$. areolata, the host DNA yields were in general the lowest in the middle of the lesion area with dark brown phloem, while the highest host DNA yields were invariably obtained in the lower lesion area with light brown phloem. When normalized against host DNA yield and expressed as fungal/host DNA amount (\%), the highest levels of $T$. areolata DNA were recorded in the area with dark brown phloem having a relatively low yield of host DNA, whereas in the lesion margins, the DNA levels of the rust declined steeply (Fig. 4).

Out of the 18 seedlings examined along the lesion area with a spatial sampling scheme, Phomopsis sp. was codetected with T. areolata in five seedlings. Regarding the saplings analyzed as a reference material, Phomopsis sp. was codetected with $T$. areolata
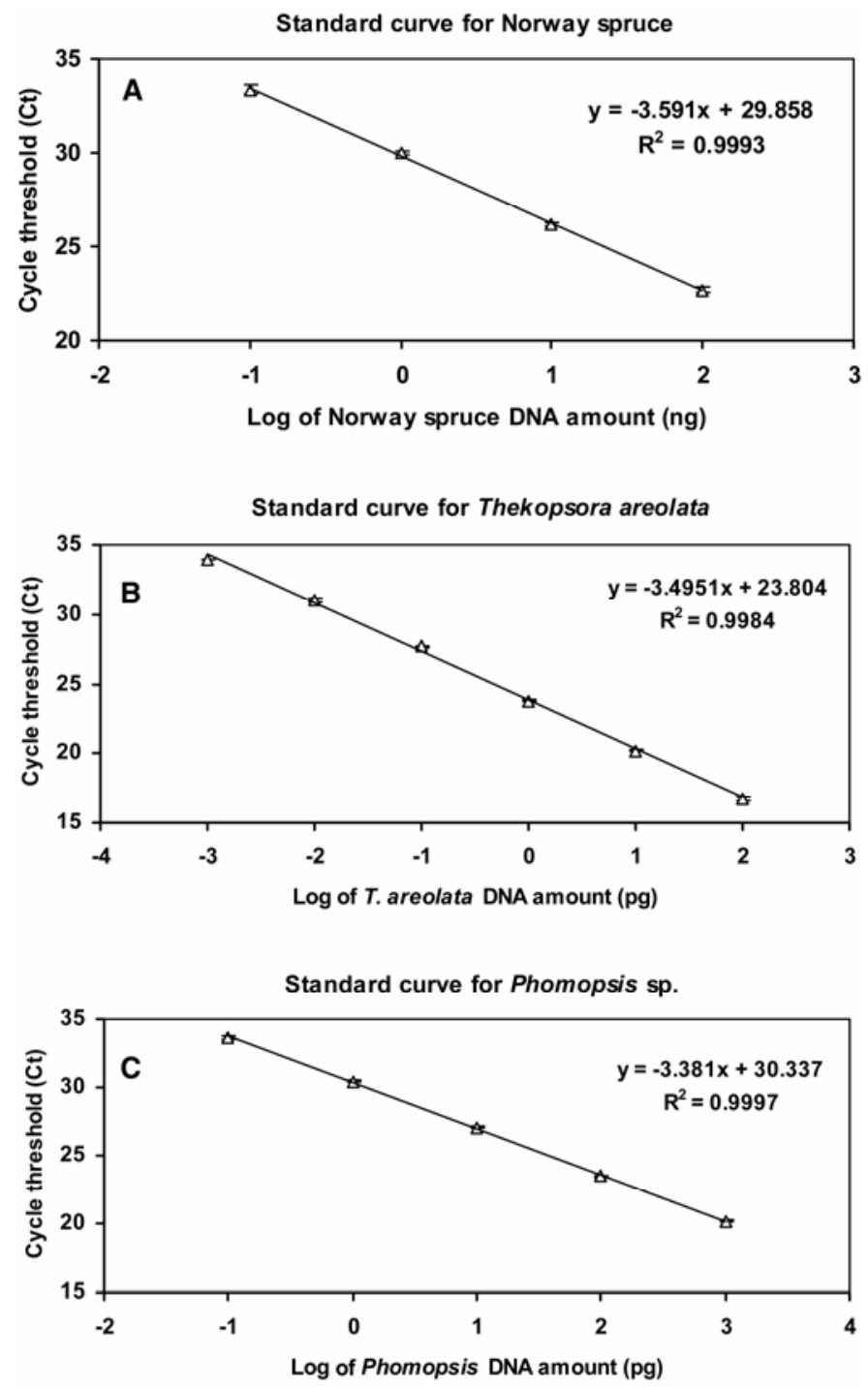

Fig. 3. Standard curves for quantifying the DNA amount of Norway spruce, Thekopsora areolata, and Phomopsis sp; log-transformed DNA amounts were plotted against cycle threshold $(\mathrm{Ct})$ values, and the linear regression equations obtained were used for calculating the amounts of the three DNA pools in experimental samples. The host DNA standard curve (A) samples (100, 10, 1, and $0.1 \mathrm{ng}$ of Norway spruce DNA) were all spiked with $1 \mathrm{ng}$ of $T$. areolata and $1 \mathrm{ng}$ of Phomopsis sp. DNA, and analyzed by the primer/probe set targeting DNA of Norway spruce. The T. areolata DNA standard curve (B) samples $(100,10,1,0.1,0.01$, and $0.001 \mathrm{pg}$ of DNA) were all spiked with 1 ng of Norway spruce and $1 \mathrm{ng}$ of Phomopsis sp. DNA, and analyzed by the primer set targeting DNA of the rust fungus. The Phomopsis DNA standard curve (C) samples $(1,000,100,10,1$ and $0.1 \mathrm{pg}$ of Phomopsis DNA) were all spiked with $1 \mathrm{ng}$ of Norway spruce and $1 \mathrm{ng}$ of $T$. areolata DNA, and analyzed by the primer/probe set targeting DNA of Phomopsis. Three PCR replicates were run on each sample. 

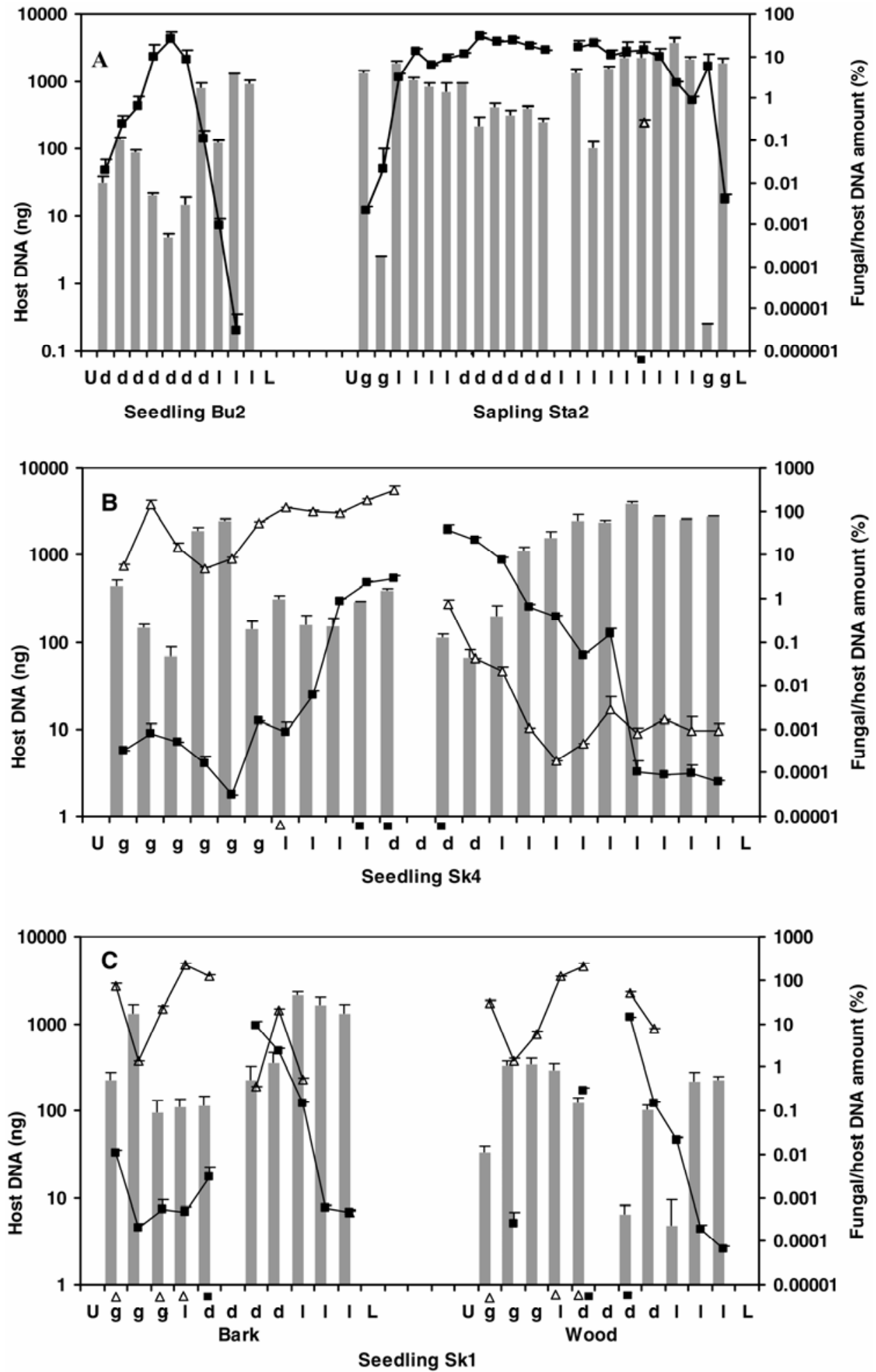

Fig. 4. The total host DNA yields (columns) and the percentage of Thekopsora areolata (line with filled squares) and Phomopsis (line with open triangles) DNA amount in relation to host DNA amount within stem lesions of Norway spruce. The values are the means + standard deviations of duplicated polymerase chain reactions (PCR) from 10- and 100-fold diluted DNA samples. The $x$ axis labels "U" and "L" indicate the orientation of the lesion (U, upper margin; L, lower margin), while the color of phloem in each sampled section is indicated by letters (g, green; d, dark brown; 1, light brown). To confirm the presence of $T$. areolata and Phomopsis sp. in the studied seedlings, sequence analysis of internal transcribed spacer (ITS) rDNA PCR products was performed on selected samples; filled squares and open triangles under the $x$ axis indicate positions where the presence of $T$. areolata or Phomopsis sp., respectively, was verified also by sequence analysis. A, Host DNA yields and pathogen colonization profiles in the seedling Bu2 and the sapling Sta2: in the seedling the shoot above the lesion was dead and the lesion area was sampled spatially by taking 5-mm-long stem sections. In the sapling, the shoot above the lesion was alive and the lesion margins were sampled spatially by taking $5 \times 2 \mathrm{~mm}$ (length $\times$ width) bark sections, while the middle of the lesion (8-cm-long area with dark or light brown phloem) with missing data was not analyzed. B, Host DNA yields and pathogen colonization profiles in the seedling Sk4. The shoot above the lesion was alive, and the lesion margins were sampled spatially by taking 5-mm-long stem sections, while the middle of the lesion (4-cm-long area with dark brown phloem) with missing data was not analyzed. C, Host DNA yields and pathogen colonization profiles in bark and wood of seedling Sk1. The shoot above the lesion was alive. The lesion margins were sampled spatially by taking 5-mm-long stem sections, while the middle of the lesion $(5.5-\mathrm{cm}$-long area with dark brown phloem) with missing data was not analyzed. From each 5$\mathrm{mm}$-long section, the bark and wood were processed separately; the samples shown at identical positions in the panels originate from the same stem sections. 
in one of the three saplings analyzed, but its presence was restricted to a single sampling position (Fig. 4A). In contrast to T. areolata, high levels of Phomopsis sp. DNA were observed particularly in the upper part of the lesion with light brown phloem and even in healthy-appearing bark with green phloem, and often there was no steep decline in its DNA levels even at the lesion margins (Fig. 4B, upper lesion). The third monitored pathogen, G. abietina, was not detected in any of the examined Norway spruce material. The ITS rDNA PCR and sequencing performed for verification of the real-time PCR data confirmed the presence of T. areolata and Phomopsis sp. in the seedlings analyzed (Fig. 4). While these T. areolata sequences obtained by direct sequencing of the PCR products showed 98 to $100 \%$ similarity to those obtained by cloning from seedlings, saplings, and cones of Norway spruce and from leaves of wild bird cherry the Phomopsis sp. sequences obtained here were 99 to $100 \%$ similar to those of the Phomopsis sp. recently characterized by Børja et al. (3).

In order to investigate fungal spread within different tissue types, five seedlings were sampled in such a way that the bark was separated from the wood, and these tissues were processed separately. For both T. areolata and Phomopsis sp., the colonization profiles, when using host DNA yield as the normalizer, were similar between the tissue types (Fig. 4C), but in the lesion margins, bark contained regularly higher normalized DNA levels of the rust than wood.

\section{DISCUSSION}

By amplifying the ITS1-5.8S-ITS2 region of $T$. areolata from DNA of diseased nursery-grown Norway spruce seedlings and comparing it to $T$. areolata sequences obtained from cones and saplings of Norway spruce and from leaves of wild bird cherry, we showed that this wide-spread pathogenic rust is commonly associated with stem lesions in container-grown 2-year-old seedlings of the conifer. The symptoms observed in these seedlings are similar to those observed in saplings infected frequently by the rust in forest conditions. In laboratory experiments published in 1900, Klebahn (11) was able to artificially inoculate shoots of Norway spruce seedlings with basidiospores of the pathogen; no fruit bodies were formed in those experiments, but the author noted the strong smell of sugary liquid exuded by pycnia. Based on fruit body observations, Roll-Hansen (19) in the 1940s showed the presence of $T$. areolata on 3- to 4-year-old nursery seedlings of Norway spruce. Otherwise there are no reports of young spruce seedlings hosting this rust. This is most likely due to the fact that the rust is difficult to culture in artificial media, and that the conspicuous aecidia allowing conventional identification of the fungus are not formed in the currently produced 2-year-old Norway spruce seedlings. In Norway spruce saplings, aecidia of T. areolata develop inside the bark and the poorly developed bark of young seedlings compared with that of saplings may explain the absence of fruit bodies in nursery seedlings. An alternative explanation is that mating, an event preceding aecidia formation, does not commonly take place in nursery conditions.

Based on inoculation experiments $(11,19,22)$, T. areolata is regarded to alternate between the conifer spruce (Picea) and broadleaved trees in the genus Prunus in order to complete its life cycle. Our comparison of ITS rDNA sequences of $T$. areolata from the different hosts/tissue types is in agreement with this concept, as ITS rDNA sequence variants specific to the hosts/tissue types were not detected. According to our preliminary observations and depending on annual weather conditions and locality of the nursery, up to four Norway spruce seedlings per a 96-seedling container tray can show symptoms characteristic of T. areolata infection. The affected seedlings are typically not located as a group but scattered within the nursery field and also within the container trays, which would be in accordance with an airborne inoculum, i.e., air-current spread of basidiospores formed on fallen leaves of wild bird cherry. The incidence of T. areolata on sapling shoots of Norway spruce in forest conditions has been shown to depend on their distance to wild bird cherry (13). Thus, eradication of this alternate host from the immediate vicinity of affected Norway spruce nurseries should be recommended.

Based on a phylogenetic analysis of the $28 \mathrm{~S}$ rDNA sequence, Maier et al. (14) concluded that the genus Thekopsora is polyphyletic and that $T$. areolata is closely related to Cronartium spp. This is compatible with our ITS sequence data as, among the deposits in the NCBI GenBank sequence database, the pine stem rust fungi $C$. ribicola and $C$. flaccidum showed high sequence similarity in the ITS regions to T. areolata. Puccinia kuehnii (a leaf rust of sugarcane) and Peridermium harknessii (a stem rust of pine), the other reference species with high sequence similarity to T. areolata in the ITS regions, were unfortunately not included in the study of Maier et al. (14).

The recently introduced real-time PCR procedure provides a robust tool for detecting and quantifying unculturable pathogens, such as rust fungi, in their natural substrates (2). For designing the real-time PCR assay, we employed an ITS1-5.8S-rDNA region that is species-specific to T. areolata to ensure specificity. Due to the high copy number of ITS rDNA gene cluster in the genome, the ITS-based detection is about 100 times more sensitive than an assay detecting a single copy gene (18). The lowest point in the standard curve for $T$. areolata was $0.001 \mathrm{pg}$ of DNA, which equals $0.965 \mathrm{Mbp}$ DNA (1 pg DNA = $965 \mathrm{Mbp}$ [1]). The genome sizes of T. areolata and other Thekopsora species are not known, but as reviewed by Leonard and Szabo (12), in the rust genus Puccinia, the genome sizes range between 67 and $154 \mathrm{Mb}$. We thus conclude that our real-time PCR assay should be able to quantitatively detect even single nuclei of $T$. areolata.

There was a strong gradient in the amount of $T$. areolata DNA along the lesion length, with the highest levels being recorded in the area with necrotic phloem. Similar gradients in the amount of pathogen DNA have been observed in the Norway spruce-Heterobasidion annosum pathosystem for example, where pathogen DNA showed the highest levels next to the inoculation site in the bark and declined along with the distance away from this site (9). It seems obvious that the necrotic bark with high DNA levels of the rust represents initial infection sites from which T. areolata is spreading both upwards and downwards to the neighboring healthy tissues. The steep decline in DNA levels of $T$. areolata in the margin areas of the lesion coincided with the change of the phloem color from dark brown to light brown, indicating that the rust infection results in host response, leading eventually in host cell death and degradation of target DNA. The analysis of bark and wood tissues separately indicated that the rust is able to also colonize wood in the area with dark brown phloem, but its initial spread to healthy tissues neighboring the infection site presumably takes place within the bark.

In 5 out of the 18 seedlings examined in detail with a spatial sampling scheme, $T$. areolata was found to coexist with a Phomopsis sp. showing 99 to $100 \%$ ITS rDNA sequence similarity to the Phomopsis species recently characterized from Norway spruce seedlings (3). Compatible with our data, Cech and Perny (4), based on fruit body observations and fungal isolations, showed that Phomopsis spp. are commonly present in $T$. areolata-infected shoots of Norway spruce saplings in forest conditions. Based on pathogenicity tests, Børja et al. (3) concluded that this Phomopsis species is a weak pathogen depending on specific host-predisposing conditions such as abiotic stress or infection by other pathogens. Hahn (8) also describes Phomopsis occulta as a weak pathogen in conifers following injuries caused by frost, transplanting, drought, and parasitic fungi such as the white pine blister rust (Cronartium ribicola). We consider it highly likely that the Phomopsis sp. now codetected with $T$. areolata is a secondary invader benefiting from the primary infection by the rust. The fact that considerably higher maximal DNA levels were observed for Phomopsis sp. than 
T. areolata can probably be explained by their differential karyotic condition; while the vegetative stage of $T$. areolata on Norway spruce is either uni- or binucleate depending on whether spermatization has taken place, the Phomopsis sp. has multinucleate cells in the vegetative stage (A. M. Hietala, H. Solheim, and C. G. Fossdal, unpublished observation).

Suppression of host defense responses, such as the hypersensitive response involving death of colonized cells, is essential for rust fungi, which rely on the success of haustoria, specialized hyphae for nutrient absorption, in extracting nutrients from living host cells (16). The fact that the Phomopsis sp. coexisting with T. areolata in the diseased seedlings showed very high DNA levels even in the healthy tissues above the lesions indicates that the fungus has a quiescent stage in the infection process. In several fruit diseases, Phomopsis species circumvent host defense responses by having a latent colonization stage during fruit development and by triggering the expression of pathogenicity factors after harvest (24). This transient type of biotrophy in which the fungus shows a biotrophic phase during early host colonization and then switches to a necrotrophic phase is referred to as hemibiotrophic (15). The initial penetration and invasion processes of a host by a fungal pathogen in the absence of a significant plant resistant response ensure successful colonization of host tissue and subsequent necrotrophic activities. Like hemibiotrophic fungi during their biotrophic stage, rusts have limited secretory activity, especially of hydrolytic enzymes, in order to minimize damages to host cells (15). It remains to be examined whether the detected Phomopsis species triggers the expression of cell-wall-degrading enzymes for example after the growing season. In any case, the mode of infection of the Phomopsis sp. resembles that of a biotroph as the fungus is apparently able to colonize spruce bark without triggering host cell death. This colonization mode undoubtedly contributes to the successful invasion of living host tissue by Phomopsis sp. and it may even facilitate its coexistence with a biotrophic rust.

Real-time PCR is currently the most sensitive quantification method for nucleic acids. Regarding quantification of infection in plants, the tool has so far been utilized for monitoring infection by singular pathogens. The multiplexing option provided by different fluorescent labels of the probe would allow simultaneous monitoring of several DNA pools in a single tube (9). Due to the high throughput nature of real-time PCR, we anticipate that the tool will become widely used also in ecological studies when monitoring events such as colonization of a common niche by several microorganisms. Besides monitoring colonization, realtime PCR can also be used for monitoring transcriptomes of the interacting host and fungi during early stages of infection (17), a situation still poorly understood in rust-host interaction.

\section{ACKNOWLEDGMENTS}

This project was financed by the Research Council of Norway (Project no. 156881/I10) and Skogforsk. The nurseries Buskerud Skogselskaps planteskole, Skogplanter Midt-Norge AS avd. Skjerdingstad, Sønsterud planteskole AS and Telemark Skogplanteskule AS provided samples, mostly via the nursery consultants M. Andersen and A. Strømberg. C. Kierulf, Skogforsk, brought some samples from Skjerdingstad. Parts of the laboratory work were performed by our technicians: O. Olsen did fungal isolations, while I. Heldal and L. Ljevo were responsible for cloning and sequencing.

\section{LITERATURE CITED}

1. Bennett, M., and Smith, J. B. 1976. Nuclear DNA amounts in angiosperms. Philos. Trans. R. Soc. London B 274:227-274.

2. Boyle, B., Hamelin, R. C., and Séguin, A. 2005. In vivo monitoring of obligate biotrophic pathogen growth by kinetic PCR. Appl. Environ. Microbiol. 71:1546-1552.

3. Børja, I., Solheim, H., Hietala, A. M., and Fossdal, C. G. 2006. Etiology and real-time polymerase chain reaction-based detection of Gremmeniella- and Phomopsis-associated disease in Norway spruce seedlings. Phytopathology 96:1305-1314.

4. Cech, T. L., and Perny, B. 1995. Pucciniastrum areolatum (Alb. Et Schw.) Liro (Uredinales) und andere Mikropilze im Zusammenhang mit Wipfelschäden an Jungfichten (Picea abies (L.) Karst.). FBVA-Berichte 88:5-28.

5. Gardes, M., and Bruns, T. D. 1993. ITS primers with enhanced specificity for basidiomycetes - Application to the identification of mycorrhizae and rusts. Mol. Ecol. 2:113-118.

6. Gäumann, E. 1959. Die Rostpilze Mitteleuropas. Buchdruckerei Büchler, Bern.

7. Govrin, E. M., and Levine, A. 2000. The hypersensitive response facilitates plant infection by the necrotrophic pathogen Botrytis cinerea. Curr. Biol. 10:751-757.

8. Hahn, G. G. 1943. Taxonomy, distribution and pathology of Phomopsis occulta and P. juniperivora. Mycologia 35:112-129.

9. Hietala, A. M., Eikenes, M., Kvaalen, H., Solheim, H., and Fossdal, C. G. 2003. Multiplex real-time PCR for monitoring Heterobasidion annosum colonization in Norway spruce clones that differ in disease resistance. Appl. Environ. Microbiol. 69:4413-4420.

10. Hiratsuka, N. 1936. A monograph of the Pucciniastreae. Mem. Tottori Agric. Coll. 4:1-374.

11. Klebahn, H. 1900. Kulturversuche mit Rostpilzen IX. Jahrb. Wissensch. Bot. 35: 660-710.

12. Leonard, K. J., and Szabo, L. J. 2005. Pathogen Profile. Stem rust of small grains and grasses caused by Puccinia graminis. Mol. Plant Pathol. 6:99-111.

13. Lilja, S. 1967. Tuomen merkityksestä kuusen tuomiruostesienen, Pucciniastrum padi (Kunze \& Schm.) Diet., esiintymiselle kuusessa. (In Finnish.) Silva Fenn. 1:45-62.

14. Maier, W., Begerow, D., Weiss, M., and Oberwinkler, F. 2003. Phylogeny of the rust fungi: An approach using nuclear large subunit ribosomal DNA sequences. Can. J. Bot. 81:12-23.

15. Mendgen, K., and Hahn, M. 2002. Plant infection and the establishment of fungal biotrophy. Trends Plant Sci. 7:352-356.

16. Mendgen, K., Struck, C., Voegele, R. T., and Hahn, M. 2000. Biotrophy and rust haustoria. Physiol. Mol. Plant Pathol. 52:95-114.

17. Mehli, L., Kjellsen, T. D., Dewey, F. M., and Hietala, A. M. 2005. A case study from the interaction of strawberry and Botrytis cinerea highlights the benefits of co-monitoring both partners at genomic and mRNA level. New Phytol. 168:465-474.

18. Nielsen, K., Yohalem, D. S., and Jensen, D. F. 2002. PCR detection and RFLP differentiation of Botrytis species associated with neck rot of onion. Plant Dis. 86:682-686.

19. Roll-Hansen, F. 1947. Nytt om lokkrusten (Pucciniastrum padi). (In Norwegian.) Medd. Norske Skogforsk. Ves. 9:503-510.

20. Roll-Hansen, F. 1965. Pucciniastrum areolatum on Picea engelmannii. Identification by spermogonia. Medd. Norske Skogforsk. Ves. 20:389397.

21. Saho, H., and Takahashi, I. 1970. Notes on the Japanese rust fungi VI. Inoculation experiments of Thekopsora areolata (Fr.) Magnus, a cone rust of Picea spp. in Japan. Trans. Mycol. Soc. Jpn. 11:109-112.

22. Tubeuf, C. 1900. Vorläufige Mitteilungen über Infektionsversuche mit Aecidium strobilinum. Cbl. II Bact. 6:428-429.

23. Wiethölter, N., Graessner, B., Mierau, M., Mort, A. J., Moersbacher, B. M. 2003. Differences in the methyl ester distribution of homogalacturonans from near-isogenic wheat lines resistant and susceptible to the stem rust fungus. Mol. Plant-Microbe Interact. 16:945-952.

24. Zhang, J. X., Bruton, B. D., and Biles, C. L. 1997. Polygalacturonase isozymes produced by Phomopsis cucurbita in relation to postharvest decay of cantaloupe fruit. Phytopathology 87:1020-1025. 